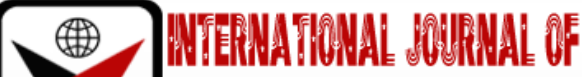

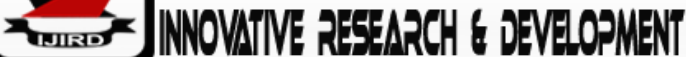

ISSN 2278-0211 (Online)

\section{Effects of Mastery and Conventional Learning Instructional Strategy on Students' Achievement in Economics in Anambra State Public Secondary Schools, Nigeria}

Anene, Cornelius Onyeka
Lecturer, Department of Educational Foundations,
Chukwuemeka Odumegwu Ojukwu University, Igbariam, Nigeria
Adinna,Patricia Ifeyinwa
Lecturer, Department of Educational Foundations,
Chukwuemeka Odumegwu Ojukwu University, Igbariam, Nigeria
Ifejiofor, Adaobi Patricia
Lecturer, Department of Educational Foundations,
Chukwuemeka Odumegwu Ojukwu University, Igbariam, Nigeria

\begin{abstract}
:
This study examined the effects of mastery and conventional learning instructional strategies on students' achievement in economics in Anambra state public secondary schools. Three research questions and three null hypotheses guided the study. Non-equivalent pretest and posttest of quasi-experimental design was employed in the study. The population for this study consisted of 2384senior secondary one (SS1) students in the 47 public secondary schools in Aguata Education Zone of Anambra State. A sample of 180 (senior secondary year one (SS1)) students which consisted of 95 males and 85 females were selected for the study. Stratified sampling technique was used. Two schools were selected from Aguata, one from Orumba North and one from Orumba South. Also, purposive sampling was used to select all the four intact classes for the selected schools. Validated instrument for data collection was Economics Achievement Test (EAT) which comprised 25 multiple choice items. Section A solicited students' background and section B was made up of 25 multiple choice questions with options A-D. The instrument has a reliability value of .94 using Kudar-Richardson $\left(K-R_{20}\right)$ test which was considered adequate for the study. The result indicated that mean achievement due to mastery learning strategy has higher mean compared to the conventional learning strategy. The study also revealed that there is a significant difference in the mean achievement of male and female students exposed to mastery learning approach and that of conventional learning approach. The study therefore concluded that mastery learning strategy is more effective in students learning of Economics better as compared to the conventional learning strategy. The study recommended among others that teachers should integrate mastery learning strategy in their classroom day to day teaching and learning process.
\end{abstract}

Keywords: Mastery learning instructional strategy, Conventional learning instructional strategy, students achievement

\section{Introduction}

Economists of any nation advise the president on various economic issues. They also formulate policies for national economic growth and development and help in analyzing economic conditions for viable investment in banks, brokerage houses, real estate companies, and other private sector businesses. They are well known for contributing to the vital development of other public sector policies such as school reform, welfare, health care and efforts to reduce inequality, pollution and crime (Jeff, 2010).

The study of economics cannot be neglected in terms of its contribution in providing valuable knowledge for daily business decision making in everyday life of individuals, businesses, and government among others. It provides a means with which to tackle questions that are desirable or useful to a particular financial investment opportunity.

In the classroom, every student relies on the curriculum programme and depends on the teaching approach chosen by the classroom teachers. Each student brings individual learning characteristics to the classroom. A programme disregarding these individual differences may not yield a better result in the performance of students who are inclined towards the selected programme. The type of teaching methods used may begin to bridge the gaps in the learner differences.

Learner-centred instruction, also known as learner-centred education, comprises of the teaching approach that centred its target instruction to the learner (student). More so, it is learner-centred instruction that aims to improve learner autonomy and self-determination by placing learning responsibility in the students' hands. Learner-centred 
instruction focuses on knowledge, capabilities, capacities, skills competencies and practices that could enable the students' lifelong learning and self-determination for problem-solving. Learner-centred education is based on the constructive learning theory that postulates the learner's critical role in using prior experiences and new information to construct meaningful learning.

Teachers are believed to continue employing approach that encourages students to involve actively in the teaching and learning process. Teaching-learning activity considers classroom situations. The goal of classroom teachinglearning is to improve learning outcomes that meet societal needs. Teachers engage in instructional techniques that bring about interactions among students and improve relationships among themselves in the classroom situation. Several teaching methods and strategies have been documented as being efficacious in teaching, increasing achievement, and aptitude towards technical subjects (MacMillan, 2007; Banks, 2008). Among these instructional approaches are the conventional instructions and mastery learning approach. Although, there are many instructional methods but this study will focus on only the conventional instructions and mastery learning approach.

Conventional instruction is regarded as the customary method which refers to long-established teacher-in-charge instructional way that societies traditionally use in schools. The conventional teaching approach which entails the teacher teaching (doing the talking) and the students learning (doing the listening), involves a formal setting of expository classroom activities on certain subject matter to achieve a stated instructional objectives. The main business of conventional instruction is to transmit to next generation the knowledge, skills, norms, facts and standards of moral and social conduct that is considered to be necessary for success in generations after them. Dewey (2008) described it as being 'imposed from above and from outside'. The students are expected to be docile and obedient as they receive and believe materials presented to them without doubt or question. Teachers are the entity to which this skills and standard knowledge is being communicated and standards of behaviour enforced. The technique of conventional instruction is simple and very often involves oral recitation. In this model, students sit calmly and listen to the teacher in their various positions in the classroom setting, and students recite the lessons when teacher needs feedback.

Mastery-learning as an approach to instruction is adopted in order to enhance and improve the learners' knowledge and ability for him/her to achievement more valued. Sufficient time, attention and help are granted to each student. Mastery-learning model of instruction argue that all students can learn effectively when given the appropriate and conducive learning conditions and context in classroom. The application of mastery-learning is based on learning objectives for cognitive domain reviewed by Black (2011). The main target of mastery learning method of instruction is to ensure that all students learn the basic instructional material at abruptly equivalent to high levels. Instructors who use mastery learning approach breakdown the subject-matter into manageable units.

In their review of mastery learning programme, Kulik, Kulik and Bangert-Drowns (2010) cited Bloom's model where by students receive individualized instruction as necessary so that they all master course material. Kulik (2011) also describe a second influential mastery model, namely Keller's (2010) personalized system of instruction (PSI). PSI has four distinguishing characteristics. First, written materials rather than lectures constitute the major teaching activity. Instead of presenting information to students orally, instructors select and create appropriate reading materials, create behavioural objectives and study questions and prepare multiple forms of tests that measure student's progress and provide feedback. Second, students finish assignment at their own pace. This principle stems from the recognition that students have many other obligations and learn at different rates. Third, students demonstrate mastery on test or correct deficiencies before they move on in their work. Finally, instructional staff resources are devoted to helping students deal with their deficiencies and weak spots.

The mastery learning approach was developed by Bloom (1971). It was based on a theoretical model developed by Carroll (1963) which states that the degree of learning acquired by a learner is proportional to the time spent on the learning, divided by the time needed for the learning. The model is based on the assumption that instructions will be of good quality and appropriate for the students. If instruction of poor quality is given more time which will be needed to master the learning. Bloom's development of mastery learning method from this model entails on the postulation that most of the students, if not all, can learn the basic skills that form the core of the school curriculum when the instruction is of good quality and appropriate for the learner. Advocates of mastery approach have proposed that almost all students can acquire adequate levels of the basic skills taught in the normal school curriculum when mastery procedure are used (Bloom, 1971).

The effects of gender on the students' learning ability, achievement and interest cannot be underestimated. Studies of this nature over the years revealed that gender is a determinant factor in terms of learning ability, achievement and interest in various subjects in schools. Studies have also shown that there is significant difference in students' choice of subject and their performance in science and non-science subjects. Olarewaju (2008) reported a significant difference between boys' and girls' achievement in the knowledge of biology concepts. Boys in this report indicated to achieve better than girls. Akinbobola (2009) also conducted a research to determine if gender is a factor in the selection of science subjects. His result revealed that gender is not a factor in the selection of science subject.

Adeqive (2011) attributes that there is difference in the learning ability of male and female students in terms of socialization process. This, he opined that female students have less privilege to schooling and pre-schooling experience for problem solving that especially involve $\mathrm{v}$

The current approach of teaching in most of the Nigerian educational institutions are based on the behavioural learning theories which are content driven, not learner-centered, and do not sufficiently give students the opportunities to participate in the classroom instruction. Students taught with methods based on the behavioural theories do not sufficiently retain their learning and apply it to new situations. The methods employed by educators seem inadequate for equipping students studying Economics with the workplace skills, knowledge and attitude required for work in businesses 
which is fast changing with advancement in technology. Thus, to reverse the problem of students' low achievement and meet the societal and industrial needs, there is need for innovative and more effective instructional methods/techniques to be used by teachers in all economics classrooms.

Furthermore, teaching and learning encompass different models of instruction for successful learning to take place on the part of students. It has been observed that some instructional factors influence learning more successfully than others do. Such factors as viewed could be as a result of models of instructions being used by the teachers. Sometimes, teachers employ models that are not suitable to the students' learning ability, developmental level and learning characteristics. This tends to affect students' performance. Therefore, there is need to determine the effect of mastery and conventional strategies on students' academic achievement in Economics in public secondary schools in Anambra State.

\subsection{Purpose of the Study}

The purpose of the study is to examine the effect of mastery and conventional learning strategies onstudents' academic achievement in Economics in senior public secondary schools in Aguata Education Zone of Anambra State. Specifically, the study sought to:

- Determine the effect of mastery and conventional learning strategies on mean economics achievement scores of students.

- $\quad$ Determine the influence of gender on the mean economics achievement scores of students.

- Determine the interaction effect of teaching strategies and gender on the mean economics achievement scores of students.

\subsection{Scope of the Study}

The geographical scope of the study is limited to only public secondary schools in Aguata Education Zone in Anambra State while the content scope is focused on the effect of mastery and conventional learning strategies onstudents' academic achievement in Economics in senior public secondary schools in Aguata Education Zone of Anambra State.

\subsection{Research Questions}

The following research questions guided the study:

- What is the effect of mastery and conventional learning strategies on mean economics achievement scores of students?

- What is the influence of gender on the mean economics achievement scores of students?

- What is the interaction effect of teaching strategies and gender on the mean economics achievement scores of students?

\subsection{Hypotheses}

The following null hypotheses guided the study and were tested at .05 level of significance.

- There is no significant difference in the mean Economics achievement scores of students exposed to mastery learning strategy and of those who were taught using the conventional teaching strategy.

- Gender has no significance influence on the mean economics achievement scores of students.

- There is no significant interaction effect of teaching strategies and gender on the mean economics achievement scores of students.

\section{Method}

\subsection{Research Design}

The study employed the quasi-experimental design of non-equivalent pre-test post-test design.

\subsection{Area of the Study}

The study was conducted in Aguata education zone of Anambra State, Nigeria.

\subsection{Population of the Study}

The population for this study consisted of 2384 senior secondary one (SS1) students in the 47 public secondary schools in Aguata education zone of Anambra State.

\subsection{Sample and Sampling Technique}

A sample of 180 senior secondary school form one (SS1) students which consisted of 95 boys and 85 girls were selected for the study. In drawing the sample for the study, stratified sampling technique, simple random sampling technique and purposive sampling were adopted for the study

\subsection{Instrument for Data Collection}

The instrument was developed by the researcher. The study instrument was Economics Achievement Test (EAT) which comprised of 25 multiple choice items from senior secondary school form one (SS1) syllabus. Section A solicited students' background, and section B is made up of 25 multiple choice questions with options A-D 


\subsubsection{Validation of the Instrument}

The instrument was validated by two experts who include an educational psychologist and an educational psychometrics. These ratters are professors in these fields from ChukwuemekaOdumegwuOjukwu University Anambra State (see Drafts in the Back). The experts were requested to examine the instrument with regards to relevance and accuracy of items, clarity of language and comprehensiveness of the items bearing in mind the purpose of the study, research questions and hypothesis.

\subsection{Reliability of the Instrument}

The items were trial tested on 25 students in four schools different from those used for the study. The schools were selected from Awka education zone in Anambra State. Kudar-Richardson $\left(\mathrm{K}-\mathrm{R}_{20}\right)$ method was used to estimate the internal consistency of the instrument. K- $\mathrm{R}_{20}$ is a special case of Cronbach alpha, computed for dichotomous scores. It is often claimed that a high KR-20 coefficient (e.g., > 0.90) indicates a homogeneous test. The analysis of the results was done using Statistical Package for Social Science (SPSS). The reliability coefficient of EAT with the use of K-R20 is .94 which was considered adequate for the study

\subsection{Experimental Procedure}

The study duration was five weeks. However, one week was used in training the research assistants and the other four weeks were used for the actual experiment. The researcher prepared the lesson plan on the subject using two approaches: the mastery and the conventional learning approach. The economics class teachers of the students were used for this experiment to remove the attendant problem of having a strange person teaching the students. The researcher has to train four research assistants on the teaching method of mastery learning using the lesson plan before the experiment commenced. The training involved practical demonstrations of the procedure by the research assistants with a class of SSI students in another school within the vicinity and it lasted for 10 working days before the researcher was convinced that the research assistants had mastered the procedures.

The first day was on the procedures of the mastery approach in teaching for the experimental groups. Day two was spent on the use of the lesson plans with particular attention to the use of mastery learning approach which is the one that was novel to the research assistants. The third and fourth days were for practical demonstration of the procedures involved in implementation using a class of SS1 in another school within the locality. The fifth day was rehearsals the assistants, the assistants applied the lesson plans prepared and validated by the researcher during the training periods, doubts raised were cleared and misconceptions straightened.

The role of the researcher during the experimental period was simply supervisory to ensure that the lesson plans were adhered to strictly. The EAT was administered first on the sample (experimental and control groups) before the commencement of the experiment to account for possible pre-existing difference in the overall ability between the experimental and control groups, and was used as a covariate measure. In order to minimize pre-test sensitization, the EAT was collected back from the students immediately after pre-testing and properly kept by the researcher. No teaching was carried out before the administration of the instrument. The students were only given the topics and asked to prepare for a test on them; this equally helped to ascertain both the effect of the treatment and the homogeneity of the two groups.

Data from the administration of the test were collected before the commencement of the experiment.

The experimental groups were taught the stipulated topics with the mastery learning approach, whereas the control groups were taught with the conventional learning approach. Their regular economics teachers who served as research assistants taught both groups. The teacher variable was held constant so that whatever observed difference could be attributed to the experimental treatment and not due to difference in the effectiveness of the teachers. Experimental group's mode of instruction involved all the practical teaching of mastery methods. On the other hand, the control group's mode of instruction was mainly lecture and demonstration by the teacher with little activity by the students.

The lesson plans for both groups, however, was same in terms of content, basic instructional objectives and length of time for teaching. Since intact classes were used for the study, the experiment was carried out during the normal economics lesson period of the classes. The teaching lasted for four weeks of twelve periods and during the normal continuous assessment test period of the schools the following week; the EAT instruments were re-administered to both groups to determine their achievement scores.

The administrations of the tests to both groups were done by the research assistants, and the researcher. At the expiration of the time for the test during each administration, scripts were collected, marked and recorded by the researcher for analysis.

\section{Method of Data Analysis}

In analysing the data, the researcher used mean scores and standard deviation in answering the research questions while Analysis of Covariance (ANCOVA) was used to test the null hypotheses at the .05 level of significance

\subsection{Data Analyses}

\subsubsection{Research Question 1}

What is the effect of mastery and conventional learning method on mean economics achievement scores of students? 


\begin{tabular}{|c|c|c|c|c|c|c|}
\hline Variable & & \multicolumn{2}{|c|}{ Pre Test } & \multicolumn{2}{c|}{ Post Test } & Std. Dev. \\
\hline Teaching Methods & No & Mean & Std. Dev. & Mean & Mean Gain \\
\hline Mastery & 88 & 58.9 & 8.61 & 71.13 & 11.26 & $\mathbf{5 . 8 3}$ \\
\hline Conventional & 87 & 42.71 & 7.04 & 45.05 & 8.13 & $\mathbf{2 . 3 4}$ \\
\hline
\end{tabular}

Table 1: Mean and Standard Deviation of Pre-Achievement Scores and Post Achievement Score of Students Exposed to Mastery and Conventional Learning Method in Economics

Analysis in table 1 shows the difference between the pre-test and post-test mean was 5.83 .

\subsubsection{Research Question 2}

What is the influence of gender on the mean economics achievement scores of students?

\begin{tabular}{|c|c|c|c|c|c|c|}
\hline Variable & & \multicolumn{2}{|c|}{ Pre Test } & \multicolumn{2}{c|}{ Post Test } & \\
\hline Gender & No & Mean & Std. Dev. & Mean & Std. Dev. & Mean Gain \\
\hline Male & 92 & 52.07 & 8.22 & 57.90 & 8.57 & $\mathbf{5 . 8 3}$ \\
\hline & & & & & & \\
\hline Female & 83 & 49.54 & 7.74 & 58.28 & 8.49 & $\mathbf{8 . 7 4}$ \\
\hline
\end{tabular}

Table 2: Mean and Standard Deviation of Pre-Achievement Scores and Post Achievement Score of Male and Female Students in Economics

Result in table 2 shows that difference between the pre-test and post-test mean achievement score for male students was 5.83 .

\subsubsection{Research Question 3}

What is the interaction effect of teaching strategies and gender on the mean economics achievement scores of students?

\begin{tabular}{|c|c|c|c|c|c|c|c|}
\hline \multicolumn{2}{|c|}{ Variable } & & \multicolumn{2}{c|}{ Pre test } & \multicolumn{2}{c|}{ Post test } & Mean \\
\hline Methods & Gender & No & Mean & Std. Dev. & Mean & Std. Dev. & Gain \\
\hline Mastery & Male & 47 & 58.7 & 8.37 & 69.75 & 10.01 & $\mathbf{1 1 . 0 5}$ \\
\hline & Female & 41 & 59.1 & 9.05 & 72.5 & 11.16 & $\mathbf{1 3 . 4}$ \\
\hline Conventional & Male & 45 & 45.44 & 8.03 & 46.04 & 9.1 & $\mathbf{. 6}$ \\
\hline & Female & 42 & 39.98 & 7.38 & 44.05 & 8.51 & $\mathbf{4 . 0 7}$ \\
\hline
\end{tabular}

Table 3: Mean and Standard Deviation of Students Overall Pre-Achievement Scores and Post-Achievement Test Scores in Economics by Teaching Strategies and Gender

Result in table 3 shows the difference between the pre-test and post-test mean achievement score for male students was 11.05 .

\subsection{Test of Hypotheses}

\subsubsection{Hypothesis One}

- $\mathrm{H}_{01}$ : There is no significant difference in the mean Economics achievement scores of students exposed to mastery learning instructional strategy and of those who were taught using the conventional teaching strategy.

\begin{tabular}{|c|c|c|c|c|c|}
\hline Source & $\begin{array}{c}\text { Type 111 Sum of } \\
\text { Squares }\end{array}$ & Df & Mean Square & F & Sig. \\
\hline Corrected Model & $127548.175^{\mathrm{a}}$ & 4 & 1095.833 & 213.137 & .000 \\
\hline Intercept & 1633.324 & 1 & 1633.324 & 96.025 & .000 \\
\hline Posttest score & 565.971 & 1 & 565.971 & 5.862 & .012 \\
\hline Groups & 2168.753 & 1 & 2168.753 & 44.529 & .000 \\
\hline Gender & 35.264 & 1 & 35.264 & 8.237 & .001 \\
\hline Group*Gender & 28.509 & 1 & 28.509 & 12.973 & .000 \\
\hline Error & 13487.510 & 170 & 83.036 & & \\
\hline Total & 7230.000 & 175 & & & \\
\hline Corrected Total & 897.667 & 174 & & & \\
\hline
\end{tabular}

Table 4: Summary of Analysis of Covariate (ANCOVA) on the Significance Difference in the Mean Achievement Scores of Students Taught Economics Using Mastery Learning Instructional Strategy and Those Taught Using the Conventional Teaching Strategy

Dependent Variable: Academic Achievement

a. $R$ Squared $=.611$ (Adjusted $R$ Squared $=.565$ ) 
The analysis in table 4 showed the summary of analysis of covariate (ANCOVA) on the significance difference in the mean achievement scores of students exposed to Economics using mastery learning instructional strategy and those taught using the conventional teaching strategy.

\subsubsection{Hypotheses Two}

- $\mathrm{H}_{02}$ : Gender has no significance influence on the mean Economics achievement scores of students.

\begin{tabular}{|c|c|c|c|c|c|}
\hline Source & $\begin{array}{c}\text { Type 111 Sum } \\
\text { of Squares }\end{array}$ & Df & Mean Square & F & Sig. \\
\hline Corrected Model & $127548.175^{\mathrm{a}}$ & 4 & 1095.833 & 213.137 & .000 \\
\hline Intercept & 1633.324 & 1 & 1633.324 & 96.025 & .000 \\
\hline Posttest score & 565.971 & 1 & 565.971 & 5.862 & .012 \\
\hline Groups & 2168.753 & 1 & 2168.753 & 44.529 & .000 \\
\hline Gender & 35.264 & 1 & 35.264 & 8.237 & .001 \\
\hline Group*Gender & 28.509 & 1 & 28.509 & 12.973 & .000 \\
\hline Error & 13487.510 & 170 & 83.036 & & \\
\hline Total & 7230.000 & 175 & & & \\
\hline Corrected Total & 897.667 & 174 & & & \\
\hline
\end{tabular}

Table 5: Summary of Analysis of Covariate (ANCOVA) on the Significance Influence on the

Mean Economics Achievement Scores of Students

Dependent Variable: Academic Achievement

a. $R$ Squared $=.611$ (Adjusted $R$ Squared $=.565$ )

The analysis in table 5 showed the summary of analysis of covariate (ANCOVA) on the significance influence on the mean Economics achievement scores of students. The result indicated that the F-ratio of 8.24 with associated probability value of .001 . Since the associated probability value of .001 was less than .05 set as the significance level, the null hypothesis which stated that gender has no significance influence on the mean Economics achievement scores of students was rejected and the alternative hypothesis accepted.

\subsubsection{Hypothesis Three}

- $\mathrm{H}_{03}$ : There is no significant interaction effect of teaching strategies and gender on the mean Economics achievement scores of students.

-

\begin{tabular}{|c|c|c|c|c|c|}
\hline Source & $\begin{array}{c}\text { Type 111 Sum } \\
\text { of Squares }\end{array}$ & Df & Mean Square & F & Sig. \\
\hline Corrected Model & $127548.175^{\mathrm{a}}$ & 4 & 1095.833 & 213.137 & .000 \\
\hline Intercept & 1633.324 & 1 & 1633.324 & 96.025 & .000 \\
\hline Posttest score & 565.971 & 1 & 565.971 & 5.862 & .012 \\
\hline Groups & 2168.753 & 1 & 2168.753 & 44.529 & .000 \\
\hline Gender & 35.264 & 1 & 35.264 & 8.237 & .001 \\
\hline Group*Gender & 28.509 & 1 & 28.509 & 12.973 & .000 \\
\hline Error & 13487.510 & 170 & 83.036 & & \\
\hline Total & 7230.000 & 175 & & & \\
\hline Corrected Total & 897.667 & 174 & & & \\
\hline
\end{tabular}

Table 6: Summary of Analysis of Covariate (ANCOVA) on the Significance Interaction Effect of

Teaching Strategies and Gender on the Mean Economics Achievement Scores of Students

Dependent Variable: Academic Achievement

a. $R$ Squared $=.611$ (Adjusted $R$ Squared $=.565$ )

Result intable 6 above showed the summary of ANCOVA on the significance interaction effect of teaching strategies and gender on the mean Economics achievement scores of students. The result indicated that the F-ratio of 12.98 was obtained with associated probability value of .000 . Since the associated probability value of .000 was less than .05 set as the significance level, the null hypothesis which stated that there is no significant interaction effect of teaching strategies and gender on the mean Economics achievement scores of students was rejected and the alternative hypothesis accepted.

\subsection{Effect of Mastery Learning Instructional Strategy and Conventional Learning Instructional Strategy on Mean Economics} Achievement Scores of Students

Mean Economics achievement scores of students revealed that mastery learning instructional strategy had more effect on students' achievement in Economics than the conventional learning instructional strategy. This claim has further been supported by the post-test means.

The mastery learning instructional strategy increase students' achievement in Economics than conventional teaching strategy. Students learn also when they are given the opportunities of discovering for themselves new truths, new 
rules, new methods of tackling things and assessing their comprehension and ability (Cheta\&Ochiama, 2018). According to Isrameiya and Uwameiye (2018), explicitly, when the students perceive a teacher as dominative, the perception of the amount of self-initiated work they perform will be negatively related to that dominative interaction. The teachers' domination of the teaching-learning process in the conventional learning instructional strategy has affected the mean achievement scores of the students in the control group.

\subsection{Influence of Gender on the Mean Economics Achievement Scores of Students}

Findings on the influence of gender on the mean Economics achievement scores of students showed that female students have higher mean achievement than the male students in Economics. The study indicated that for each of the groups, the post-test means achievement score was greater than the pre-test mean achievement score with the female students having higher main gain. The study also indicated that gender has a significance influence on the mean Economics achievement scores of students with the female students having higher mean gain than male students. This finding is in consonance with that of Pepple (2014), in which he reported that students' achievement towards Chemistry was significantly dependent of gender. He noted that male students achieve higher that their female counterparts when exposed to some Chemistry activities. However, it would appear to contradict the findings of Bashirat, Oloyede and Adekunle (2015), who reported that gender had no significant effect on the achievement of the students taught using the mastery learning instructional strategy. They opined that the mean difference in academic achievement between male and female students is very minimal.

Some studies on gender influence on students' achievement in science were of the opinion that boys are more exposed to scientific activities very early in life than girls. Moreover they are encouraged to enter for science related professions like engineering and technology while the girls go for biology, home economics and other allied subjects. Corroborating, Mitee and Obaitan (2015) noted that during the science education reforms of the 1980's, it became evident that both the pedagogical practices and the presentation of science in many classrooms reflected social and cultural stereotypes which were masculine and curriculum better suited for boys only. Though, the result of this study has shown that giving equal experience and unlimited access to education for females, girls would as well achieve better in academic activities.

\subsection{Interaction Effect of Learning Strategies and Gender on The Mean Economics Achievement Scores of Students}

Findings on the interaction effect of learning strategies and gender on the mean Economics achievement scores of students revealed that male and female students in mastery learning instructional strategy outperformed their counterparts in conventional learning instructional strategy. However, for each of the groups, the post-test means achievement score was greater than the pre-test mean achievement score. The study also showed that there is a significant interaction effect of teaching strategies and gender on the mean Economics achievement scores of students with the group taught with mastery learning instructional strategy having a higher mean gain. The male and female students taught Economics with mastery learning instructional strategy performed better than their counterparts taught with conventional learning instructional strategy. This is an indication that that mastery learning instructional strategy minimizes gender difference in achievement as the mean difference is very minimal. This finding corroborates with the findings of Oluwatosin and Olufunke (2015) who found significant interaction between instructional method and gender on students' achievement.

\section{Conclusion}

Teaching approaches from reviews have the potential to make or mar students' achievement. Mastery learning instructional strategyhas shown that the era of male dominance and supremacy over female students in Economics learning is fast winding up. The trend of male students having greater achievement than female students has been proved not to be a truism by the finding of this study. Mastery learning instructional strategy is found to increase attainment of Economics students for both the gender than conventional learning instructional strategy.

\section{Recommendations}

Based on the findings of this study, the following recommendations are made:

- The government should advocate that mastery learning instructional strategy.

- Male and female students should be given equal consideration as far as the use of mastery learning instructional strategy.

- Curriculum planners should ensure that the curriculum of teacher education in the country should include the mastery learning instructional strategy.

- Classroom teachers should adopt mastery learning approach in teaching methods in the teaching and learning of difficult concepts in economics.

- Secondary school teachers' especially Economics teachers should be encouraged to explore the application of mastery learning approach in their classroom instruction which is gender inclusive.

- Secondary school economics teachers should break the concept to be taught into small discrete units and make sure each child masters each unit before moving to the next.

Economics Achievement Test (EAT) should be administered at each unit of teaching to know students' performance levels and also to identify and address learning difficulties for further teaching and activities.

Teacher trainers should integrate mastery learning approach among instructional strategies being inculcated into the students. 
Seminars and workshops should be organized for serving teachers to keep abreast with principles and implementation process of mastery learning approach.

More teachers should be recruited to reduce class size for effective implementation of the mastery learning approach as an instructional strategy.

\section{References}

i. Jeff, A. N. (2010). Effect of innovative teaching on students' achievements in Economics.Journal of Emerging Trends in Economics and Management Sciences, 3 (3), 247-251.

ii. Iserameiya, F. E. \&Uwameiye, R. (2018).Effect of mastery learning strategy on rural and urban students' academic achievement in Basic Technology in Edo State, Nigeria.World Journal of Research and Review (WJRR), 6(6), 22-28.

iii. Kulik, C. C., Kulik, J. A. \&Bangert-Drowns, R. L. (2010). Effectiveness of mastery learning programmes: A metaanalysis. Review of Educational Research, 60(2), 265-299.

iv. Kulik, C. C. (2010). Effectiveness of mastery learning program: A meta-analysis. New York: University of Albany.

v. Pepple, T. F. (2014). Effect of mastery learning approach on secondary school students' achievement in Chemistry in Rivers State Nigeria.Chemistry and Materials Research, 6(9), 104-110

vi. .Bashirat, T. L., Oloyede, S. O. \&Adekunle, S. O. (2015).Effects of mastery learning instructional strategy on senior school students' achievement in the Mole Concept.Electronic Journal of Science Education, 19(5), 1-20.

vii. Cheta, W. \&Ochiama, A. C. (2018).Mastery learning approach versus constructivist-based learning approach on senior secondary school students' academic achievement in Biology.International Journal of Quantitative and Qualitative Research Methods, 6(1), 1-10.

viii. Adeqive, M. J. (2011). A study of interactions between structure of intellect factors and two methods of presenting concepts of modulus seven Arithmetic.Doctor's Thesis. Tallahassee: Fla. State University

ix. Akinbobola, A. 0. (2009). Effects of teaching methods and study habits on students' achievement in senior secondary school physics, using a pictorial organizer. Unpublished Ph.D Dissertation, University of Uyo.

x. Olarewaju, A. S. (2008). Assessing the relative effectiveness of three teaching methods in the measurement of students' performance in Physics.International Journals of Material, Methods and Technologies, 1 (8), $116-125$.

xi. $\quad$ Bloom, B. S. (1971).The new direction in educational review.PHI Delta Kappan, 6, 382 - 385.

xii. Mitee, T. L. \&Obaitan, G. N. (2015).Effect of mastery learning on senior secondary school students' cognitive learning outcome in quantitative chemistry.Journal of Education and Practice, 6(5), 34-38.

xiii. Oluwatosin, O. B. \&Olufunke, T. B. (2015). Comparative effect of mastery learning and mind mapping approaches in improving secondary school students' learning outcomes in Physics. Science Journal of Education, 3(4), 78-84

xiv. Macmillan, J. (2007). Classroom assessments. Boston: Allyn and Bacon.

xv. Banks, J. (2008). Introduction to multicultural education.In J. W. Santrock, Educational Psychology (4th edition). Boston: McGraw Hill.

xvi. Dewey, J. (2008). Experience and education.Kappa Delta PHI. 1 - 5.

xvii. Black, J. H. (Ed) (2011). Mastery learning: Theory and Practice. New York: Holt, Rinehart \& Winston. 